\title{
Research on the Reform of Practical Teaching of Business Administration Major in Applied Undergraduate Universities
}

\author{
Xiu Liu ${ }^{1, a}$ and Shangxin Chang ${ }^{1, b}$
}

\author{
${ }^{I}$ Nanchang Institute of Technology, Nanchang, China \\ anclg_liuxiu@163.com, ${ }^{b}$ changshangxin@nut.edu.cn
}

\begin{abstract}
With the further development of China's socialist market economy, the competition among enterprises has become increasingly fierce, and the concept of talents of enterprises has also changed. It is more inclined to introduce applied talents. Practice teaching is an irreplaceable important link for cultivating applied talents. The subject characteristics and talent training objectives of the applied undergraduate business management major determine the focus of the practical curriculum system. At present, there are certain problems in the arrangement and implementation of practical teaching in the business administration majors of the undergraduate colleges. According to Li Xingguo, Feng Jianping, Li Wei, Rao Jianing, Li Xuxuan, Li Yingxia and other scholars, this paper analyzes the current situation and existing problems of applied undergraduate business management professional practice teaching, and puts forward the basic ideas for constructing practical teaching reform of business administration major.
\end{abstract}

Keywords: applied, business management, teaching, practice

\section{INTRODUCTION}

Applied undergraduate education is different from vocational education in skills training and advanced research education based on theoretical training. It is an education that trains practical and applied high-level talents with high comprehensive quality and strong practical ability. Practical teaching is undoubtedly an important means to complete the training of applied undergraduate education talents. To adapt to the needs of the market economy and the development of the times, it is impossible to complete the mission by relying solely on theoretical teaching. Students must not only have a deep knowledge base of economics and management theory, but also should exercise their practical operational ability, adaptability, corporate environmental adaptability, independent thinking and analysis ability, and teamwork symbiosis ability through practical teaching links. The current business needs of enterprise management, marketing, decision analysis and scientific research in business and management[1].

\section{PROBLEMS IN THE PRACTICAL TEACHING SYSTEM OF BUSINESS ADMINISTRATION MAJORS IN APPLIED UNDERGRADUATE COLLEGES}

\subsection{The Traditional Business Management Professional Talent Training Mode is Seriously out of Touch with Corporate Practice}

Every autumn is the peak of recruitment. It is very difficult for business administration graduates to find a job that they are satisfied with, and most companies are also lamenting that they cannot recruit suitable business management professionals. The main reason for this problem is that the training mode of business management professionals in colleges and universities today is not linked to corporate practice. At present, the training programs of colleges and universities are mostly formulated with reference to some famous schools. Without the participation of relevant persons from the relevant enterprises, the cooperation between schools and enterprises has been greatly reduced[3].

\subsection{Lack of a Perfect Curriculum Structure System}

As far as the curriculum structure system of applied undergraduate colleges is concerned, the phenomenon of "heavy theory and light practice" has emerged, and a complete curriculum structure system is lacking. The curriculum structure is unreasonable, the theoretical professional courses are obviously more than the practical teaching links, and the course use books such as management, marketing, production operation and management are all using some famous university textbooks. These books are very detailed in theory. However, there is not much practicality in practical teaching, and there is a problem in the quality of the applied undergraduate business management professionals.

\subsection{Practice Teaching Teacher Strength is Relatively Weak}

The school lacks the "double-skilled" talents. Because teachers have a large amount of teaching work and lack of practical experience, it affects the effect of practical teaching. 
The main source of teachers in colleges and universities is graduates of higher education institutions. Although their academic qualifications may be higher, they also enter the school from the school gate. They do not have experience in the actual operation and management of enterprises and companies. They have no specific experience. This inevitably has the problem that the theory is out of touch with reality.

\subsection{The Assessment of the Practice Teaching Link is not Standardized}

In the practice teaching process, the standards and completion contents that are required to be different are different due to different practice items. Because of the weak teacher resources, the practical environment and the unfavorable factors of the infrastructure, it is impossible to implement the assessment of the students' practical teaching effects, especially the evaluation of the students' lack of effectiveness. There should be clear tasks in all aspects of practice. There should be specific standards for the assessment of objectives at all levels, and these must be made clear before the start of practical teaching. The goals of the students are clear, and the direction of their efforts is determined. This is an incentive for students and a promotion. Under the current circumstances, the assessment of students in practice links focuses on attendance, results, and the quality of reports. It does not reflect whether students achieve the expected goals through practice or whether they improve their practical ability. The results of students' practical teaching effects cannot be truly reflected. Practical ability and level[4].

\subsection{Lack of Ideal Training Internship Platform}

Since most applied colleges pay insufficient attention to the practical teaching of cultural management, the policy support and financial support obtained from practical teaching are obviously insufficient, resulting in the steel investment requirements of teaching resources (funds and places) and the negative investment willingness of schools. The contradiction between them becomes the direct reason why practical teaching is difficult to implement effectively. Although many colleges have made a lot of efforts, such as integrating the practical teaching resources of business administration, establishing a school-level business management experiment (training) center, and improving the training course system through the second class, in order to solve the shortage of software and hardware resources. But there are still two problems in the actual operation.

\section{SUGGESTIONS ON THE REFORM OF PRACTICAL TEACHING REFORM OF BUSINESS ADMINISTRATION MAJORS IN APPLIED UNDERGRADUATE COLLEGES}

Improve understanding and pay attention to practice teaching in class. According to the application-oriented undergraduate orientation and the talent training objectives of business administration, the courses offered by business administration are very practical and applicable. The theoretical teaching is inevitably boring and abstract, and it is difficult for students to understand and master. Nowadays students have the most opinions. Focus on this. Even if there are independent experimental courses or school year internships, but because of the comprehensive and design of these practices, not only for a certain course; in addition, the cycle is too long (often once a year or junior year), and student knowledge acquisition. The ability improvement is realized on the basis of learning each course. Therefore, the corresponding in-class practice teaching must be interspersed in the theoretical teaching process[3].

In-class practice is both a matter of teaching content and a teaching method. Practice is to thoroughly understand the theory and must be closely combined with the theoretical content. Practice is the reform of the traditional "full house irrigation", which makes students become passive and active, and change one-way to interaction. In-class practice should pay attention to systemic and coherent. Just as the theoretical content is systematic, the in-class practical teaching closely related to the theory is also systematic, and should also have a unified syllabus to ensure the consistency of teaching quality[1].

\subsection{Improve the Construction of Software and Hardware Facilities and Establish a Three- dimensional Mechanism for Practical Teaching}

To solve the problem of insufficient software and hardware construction facilities for practical teaching of business administration, it is necessary to construct a new comprehensive practical teaching platform for internal and external training bases, school-enterprise joints, and schoolschools. First, the establishment of a training base in the school should focus on the professional skills training of business administration. The practical training activities should enable students to get skills training in the simulated professional position environment, so that graduates have the advantage of taking jobs. In this process, schools should closely follow the trend of the times and market demand, and actively introduce practical teaching simulation software related to business administration, so that students can experience the practical operation and operation under the realistic environment of complex enterprises and institutions in the on-campus training room. Second, establish an "internship base" and an "experimental base" in the business management positions of the business enterprises, and exchange the human and scientific resources of the school with the funds and materials of the enterprise. On the one hand, teachers are sent to the company to work part-time, to understand and learn the knowledge and skills of the actual operation of business administration, and to hire people with practical work experience in business management positions to take practical teaching guidance work; on the other hand, they should also rely on local business management industry associations and Enterprises, in accordance with the principle of school-enterprise cooperation, mutual benefit, to create a school training base. Through the cooperation, scientific and technological achievements promotion, production and social services to build a long-term mechanism for school-enterprise cooperation, this can not 
only ease the contradiction of the lack of software and hardware upgrades, but also fully mobilize the enthusiasm of enterprises to participate in school- enterprise cooperation. Third, the school and school are united to build a practical platform for inter-school practice and to realize the sharing of hardware, software and personnel. The school-school combination of practical teaching has been running for some years in some 211 engineering universities. School-school integration means that a number of colleges and universities build an experimental network platform. Everyone can learn from each other's strengths and complement each other's strengths. Each participating university can share its own software and hardware for other universities free of charge, and participate in the joint platform between the teachers and students. It can be interactive; teachers can jointly write new experimental instruction books, and jointly research and develop new practical teaching projects, so that the sharing of practical teaching resources can be realized at a higher level to meet the increasingly deepening needs of practical teaching in colleges and universities[2]

\subsection{Scientific Teaching Evaluation, Standard Practice Teaching}

The final evaluation of traditional practice teaching is completed by the instructor. The standard is formulated by the instructor. Different teachers have different evaluation criteria and lack uniform assessment criteria. Therefore, a sound system should be established in determining the evaluation criteria for practical teaching effects, and macro management should be strengthened for practical teaching. In the practice teaching based on the cultivation of innovative talents, the single examination evaluation method has been unable to meet the needs of school education, especially the teaching of teachers and the cultivation of students' creative ability. Diversified evaluation methods should be adopted, such as combining quantitative assessment with qualitative analysis, combination of formative evaluation and summary evaluation, combination of relative evaluation and absolute evaluation, combination of static evaluation and dynamic evaluation, internal evaluation and external The evaluation is combined with the objective and impartial evaluation from multiple angles. The ultimate goal of the evaluation is to maximize the enthusiasm of teachers and students, to fully exploit their potential, and to publicize their individuality and interests[5].

\subsection{Focus on Cultivating the "Double-type" Teacher Team and Strive to Improve the Quality of Practical Teaching}

Improving teachers' practical teaching and guiding ability is the key to improving the quality of practical teaching. From the current situation, most of the instructors of applied undergraduate colleges lack experience in corporate work, lack of practical management experience, and lack of practical teaching and guidance skills, which makes it difficult to improve the quality of practical teaching. Therefore, focusing on cultivating a group of "double-type" teachers is the key to improving the quality of practical teaching. Schools should create conditions as much as possible to cultivate a "double-type" teacher team. First, through school-enterprise cooperation, in accordance with the talent training model, organize teachers to practice in the enterprise, let the teachers go deep into the production line for business practice, participate in research projects of enterprises, participate in product research and development and technical research, in order to improve teachers' professional skills and practical guidance skills. The second is to encourage professional teachers to work in a cooperative enterprise unit or part-time exercise, participate in business decision-making and daily management, be familiar with the operation management of the enterprise, and master the management process of the enterprise[1]

\subsection{Focus on the Construction of Teaching Materials and Rebuild the Curriculum System of Business Administration Majors}

The construction of teaching materials is an important part of the practical teaching reform of applied undergraduate business management majors. The construction of teaching materials is the key point of curriculum construction and an important part of improving the quality of practical teaching. In accordance with the requirements of applied talent training, applied undergraduate colleges and universities organize relevant experts, professors, entrepreneurs and experienced management personnel to write a set of practical, practical and practical business management professional textbooks, and constantly strengthen the practice. The construction of teaching materials in the teaching link is combined with theoretical teaching.

\section{SUMMARY}

This paper analyzes the current situation and existing problems of practical teaching of business administration in China, and then discusses the necessity and significance of constructing practical teaching system. Finally, it puts forward the construction of practical undergraduate business management professional teaching system. In order to provide some reference for colleges and universities, and to cultivate more application-oriented undergraduate business management professionals who meet the needs of the society, and hope that the school and enterprises can carry out more cooperation, and constantly improve the practical teaching system[4].

\section{REFERENCES}

[1] Li Xingguo. Construction of practical teaching system for applied business undergraduate business administration. China Management Informationization. 2016, No.2.

[2] Feng Jianping, Li Jie. Analysis on the Reform of Practical Teaching System of Business Administration Major in Applied Undergraduate Colleges. Curriculum Education Research.Study on Law and Teaching Method. 201630

[3] Rao Jianing. Reflections on the reform of practical teaching of applied undergraduate business administration major. Management observation. 2015, 25 issues. 
[4] Li Xuxuan. Problems and Countermeasures in the Practice Teaching of Business Administration Majors in Applied Undergraduate Colleges. Education Exploration. 2013 No. 2

[5] Li Yingxia. In-class undergraduate business management professional practice teaching mode. Economic and social development. 20117 issues. 